\title{
1 Supplemental Material: Deep decoupling in subduction zones: 2 observations and temperature limits
}

3

Geoffrey A. Abers', Peter E. van Keken², Cian R. Wilson ${ }^{2}$

${ }^{1}$ Department of Earth and Atmospheric Sciences, Cornell University, Ithaca NY 14853, U.S.A.

${ }^{2}$ Earth and Planets Laboratory, Carnegie Institution for Science, Washington DC 20015, U.S.A.

\section{NUMERICAL METHODS}

In this section we provide further details of the numerical model setup from Section 3.3 including the equations and boundary conditions as well as providing details on how the input files used can be accessed and run.

\subsection{Domain and equations}

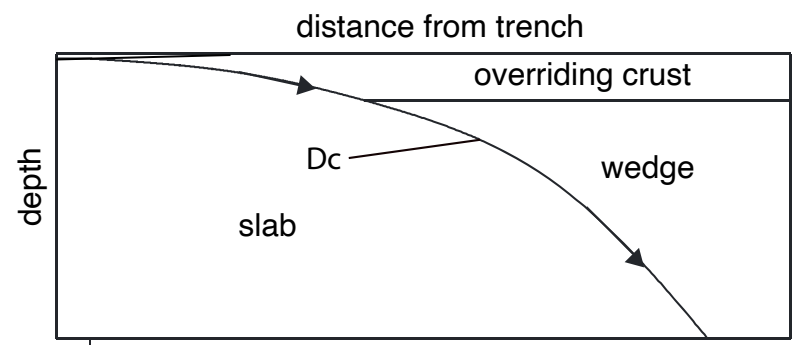

The model domain is divided into three regions: the overriding crust, the mantle wedge, and the slab. We solve separately for the velocity and pressure in the wedge and the velocity and pressure in the slab assuming the incompressible Stokes equation

$$
-\nabla \cdot\left(2 \eta \dot{\epsilon}_{i}\right)+\nabla p_{i}=0
$$

$$
\nabla \cdot \mathbf{v}_{i}=0
$$

where $\eta$ is the viscosity and $\dot{\epsilon}_{l}$ is the strain-rate tensor

$$
\dot{\epsilon}_{i}=\left(\frac{\nabla \mathbf{v}_{i}+\nabla \mathbf{v}_{i}^{T}}{2}\right)
$$

$\left(\mathbf{v}_{i}, p_{i}\right)$ are the velocity and pressure in the slab, $\left(\mathbf{v}_{s}, p_{s}\right)$, or in the wedge, $\left(\mathbf{v}_{w}, p_{w}\right)$. The velocity in the overriding crust $\mathbf{v}_{c}$ is assumed to be $(0,0)$.

Flow is driven in the slab and wedge using an internal boundary condition along the slab surface, separating the slab from the overriding crust and wedge. On the slab side this drives $\mathbf{v}_{S}$ at the convergence rate $V$ parallel to the slab surface along its entire length. On the wedge side the boundary condition for $\mathbf{v}_{w}$ is $(0,0)$ down to the coupling depth, $D c(80 \mathrm{~km}$, unless otherwise stated). It then ramps up linearly to have magnitude $V$ parallel to the slab surface over an interval of $2.5 \mathrm{~km} . \mathbf{v}_{w}=(0,0)$ along the Moho, separating the wedge from the overriding crust. All other external boundaries of the domain have zero stress (zero Neumann) boundary conditions.

Viscosity, $\eta$, follows a dry olivine rheology, $\eta_{o l}$, with a maximum viscosity cap, $\eta_{\max }$, such that 
36 where $A_{o l}, E_{o l}, R$, and $n_{o l}$ are the pre-exponential constant, activation energy, gas constant and 37 power-law exponent respectively (see Table S1). Parameters follow Karato and Wu (1993).

TABLE S1: CONSTANT EQUATION PARAMETERS

\begin{tabular}{llrl}
\hline \hline$A_{o l}$ & pre-exponential constant - dry olivine & 28968.6 & $\mathrm{~Pa} \mathrm{~s}{ }^{1 / n_{o l}}$ \\
$E_{o l}$ & activation energy - dry olivine & 540 & $\mathrm{~kJ} / \mathrm{mol}$ \\
$R$ & gas constant & 8.3145 & $\mathrm{~J} / \mathrm{mol} / \mathrm{K}$ \\
$n_{o l}$ & power-law exponent - dry olivine & 3.5 & \\
$\eta_{\text {max }}$ & maximum viscosity cap & $10^{25}$ & $\mathrm{~Pa} \mathrm{~s}$ \\
$\rho_{w}, \rho_{s}$ & mantle (wedge \& slab) density & 3300 & $\mathrm{~kg} \mathrm{~m}{ }^{-3}$ \\
$c_{p}$ & isobaric heat capacity & $1250 \mathrm{~J} / \mathrm{kg} / \mathrm{K}$ \\
$k_{w}, k_{S}$ & mantle (wedge \& slab) thermal conductivity & $3.1 \mathrm{~W} / \mathrm{m} / \mathrm{K}$ \\
$w$ & shear zone width & 500 & $\mathrm{~m}$ \\
$a_{H_{2} O}$ & water activity & 1 & \\
$A_{f_{1}}$ & water fugacity pre-exponential & 5521 & $\mathrm{MPa}$ \\
$A_{f_{2}}$ & water fugacity activation energy & $31.28 \mathrm{~kJ} / \mathrm{mol}$ \\
$A_{f_{3}}$ & water fugacity activation volume & $10^{-5}$ & $\mathrm{~m}{ }^{3} / \mathrm{mol}$ \\
$T_{m}$ & mantle potential temperature & 1350 & ${ }^{\circ} \mathrm{C}$ \\
$(d T / d z)_{a}$ & adiabatic temperature gradient & 0.3 & ${ }^{\circ} \mathrm{C} / \mathrm{km}$
\end{tabular}

We find the temperature neglecting compressible effects, $T^{*}$, by solving the heat equation on the whole domain

$$
\rho_{i} c_{p} \mathbf{v}_{i} \cdot \nabla T^{*}-\nabla \cdot\left(k_{i} \nabla T^{*}\right)-Q_{i}-\delta_{f} H=0
$$

where $\rho_{i}$ and $k_{i}$ are the density and thermal conductivity of the overriding crust $\left(\rho_{c}, k_{c}\right)$, mantle

45 wedge $\left(\rho_{w}, k_{w}\right)$ and slab $\left(\rho_{s}, k_{s}\right)$, and $c_{p}$ is the isobaric heat capacity. $Q_{i}$ is the radiogenic heat production, which is zero in the mantle wedge and slab $\left(Q_{w}=Q_{s}=0\right)$. Non-zero heating in the overriding crust is varied between the lower crust, $Q_{l c}$, and the upper crust, $Q_{u c}$ (see Table S2). Shear heating, $H$, is applied only along the slab surface, as indicated by the delta-function, $\delta_{f}=$ $\delta\left(\mathbf{s}-\mathbf{s}_{f}\right)$ where $\mathbf{s}$ is the position vector and $\mathbf{s}_{f}$ is the position of the slab surface. $H$ is defined

50 following (2)

$$
H=V_{f} \tau
$$

$$
\tau=\tau_{v} \tanh \left(\frac{\tau_{f}}{\tau_{v}}\right)
$$




$$
\tau_{f}=\mu^{\prime} \sigma_{n}
$$

$$
\sigma_{n}=\left\{\begin{array}{r}
z \rho_{c} g, z \leq \Delta z_{c} \\
\left(z-\Delta z_{c}\right) \rho_{s} g+\Delta z_{c} \rho_{c} g, z>\Delta z_{c}
\end{array}\right.
$$

$$
\tau_{v}=\frac{1}{2} B^{-1 / n}\left(\frac{V_{f}}{w}\right)^{1 / n} f_{H_{2} O}^{-r / n} \exp \left(\frac{E+\sigma_{n} V^{*}}{n R T}\right)
$$

$$
f_{H_{2} O}=a_{H_{2} O} A_{f_{1}} \exp \left(-\frac{A_{f_{2}}+\sigma_{n} A_{f_{3}}}{R T}\right)
$$

$V_{f}$ is the magnitude of the velocity jump across the slab surface, || $\mathbf{v}_{w}-\mathbf{v}_{s}||_{f}$, so follows the velocity internal boundary condition starting at the trench at the full convergence rate $V$ before linearly decreasing to zero over a $2.5 \mathrm{~km}$ depth interval after the coupling depth, $D c$, is reached (at $80 \mathrm{~km}$ unless otherwise stated). $\tau_{f}$ is the frictional stress resulting from the friction coefficient, $\mu^{\prime}$, and fault-normal stress, $\sigma_{n}$, assumed equal to lithostatic pressure. In (S11) $z$ is the depth below the surface (taking bathymetry into account), $g$ is the magnitude of the acceleration due to gravity, and $\Delta z_{c}$ is the crustal thickness. $\tau_{v}$ is the differential stress in a ductile shear zone of width $w$, where $f_{\mathrm{H}_{2} \mathrm{O}}$ is an approximation to water fugacity (Shinevar et al., 2015) and $B, n, r$, $E$ and $V^{*}$ are laboratory-derived flow parameters specific to the assumed rheology (see Table S3). $a_{H_{2} O}, A_{f_{1}}, A_{f_{2}}$ and $A_{f_{3}}$ are the water activity and other constants related to the water fugacity law (see Table S1).

Since we have simplified the modeling to neglect the effect of compression (which is what causes the adiabat) it is useful, when comparing our model results to natural conditions at depth, to add the adiabatic heating effect such that:

$$
T=T^{*}+\left(\frac{d T}{d z}\right)_{a} Z
$$

where $(d T / d z)_{a}=0.3^{\circ} \mathrm{C} / \mathrm{km}$ is the assumed linear adiabatic gradient added a posteriori to the

73 model temperature, $T^{*}$, to reconstruct the full temperature, $T$, used in (S12), (S13) and (S5) and presented in all figures and results. 
TABLE S2: CASE-DEPENDENT PARAMETERS

\begin{tabular}{|c|c|c|c|c|c|c|c|}
\hline & & Idealized & $\begin{array}{c}\text { Alaska } \\
\text { Peninsula }\end{array}$ & Nicaragua & $\begin{array}{c}\text { N. } \\
\text { Honshu }\end{array}$ & $\begin{array}{c}\text { WA } \\
\text { Cascades }\end{array}$ & units \\
\hline \multicolumn{8}{|c|}{ Thermal model parameters } \\
\hline$\rho_{c}$ & crustal density & 3300 & 2750 & 2750 & 2750 & 2750 & $\mathrm{~kg} \mathrm{~m}^{-3}$ \\
\hline$k_{c}$ & $\begin{array}{l}\text { crustal thermal } \\
\text { conductivity }\end{array}$ & 3.1 & 2.5 & 2.5 & 2.5 & 2.5 & $\mathrm{~W} / \mathrm{m} / \mathrm{K}$ \\
\hline$Q_{u c}$ & $\begin{array}{l}\text { upper crust heat } \\
\text { production }\end{array}$ & 0 & 1.3 & 1.3 & 1.3 & 1.3 & $\mu \mathrm{W} \mathrm{m}{ }^{-3}$ \\
\hline$Q_{l c}$ & $\begin{array}{l}\text { lower crust heat } \\
\text { production }\end{array}$ & 0 & 0.27 & 0.27 & 0.27 & 0.27 & $\mu \mathrm{W} \mathrm{m}{ }^{-3}$ \\
\hline$\Delta z_{u c}$ & upper crust thickness & 20 & 15 & 15 & 15 & 15 & $\mathrm{~km}$ \\
\hline$\Delta z_{c}$ & total crust thickness & 50 & 35 & 30 & 40 & 40 & $\mathrm{~km}$ \\
\hline \multicolumn{8}{|c|}{$\mathrm{H}_{2} \mathrm{O}$ flux parameters } \\
\hline \multirow{3}{*}{\multicolumn{2}{|c|}{$\begin{array}{l}\text { Sediment thickness (trench) } \\
\text { Sediment thickness ( } \geq 15 \mathrm{~km} \text { depth) } \\
\text { Sediment type }\end{array}$}} & 0 & 0.8 & 0.5 & 0.6 & 2.5 & $\mathrm{~km}$ \\
\hline & & 0 & 0.4 & 0.3 & 0.3 & 0.4 & $\mathrm{~km}$ \\
\hline & & - & turbidite & carbonate & diatom & pelagic & Table S5 \\
\hline \multirow{2}{*}{\multicolumn{2}{|c|}{$\begin{array}{l}\text { Domain depth } \\
\text { Domain width }\end{array}$}} & 230 & 240 & 240 & 240 & 290 & $\mathrm{~km}$ \\
\hline & & $\begin{array}{c}230 / \tan (\Delta) \\
+20\end{array}$ & 412 & 255 & 560 & 586 & $\mathrm{~km}$ \\
\hline
\end{tabular}

The temperature neglecting adiabatic effects is found using a halfspace cooling model as 80 a boundary condition on the left-hand, slab side of the domain. A mantle potential temperature,

$81 T_{m}$, of $1350^{\circ} \mathrm{C}$ is assumed. On the right-hand, wedge and overriding crust side of the domain a 82 continental geotherm based on a surface heat flow of $65 \mathrm{~mW} / \mathrm{m}^{2}$ is applied using the analytical 83 solution of the 1D heat equation with heat production in the upper and lower crust, $Q_{u c}$ and $Q_{l c}$. 84 The right-hand boundary condition is capped at $T_{m}$. Zero Dirichlet and Neumann boundary 85 conditions are applied to the top and bottom of the domain respectively. 
TABLE S3: RHEOLOGY-DEPENDENT PARAMETERS

\begin{tabular}{|c|c|c|c|c|c|c|c|c|}
\hline & & $\begin{array}{l}\text { WETQZ } \\
\end{array}$ & "WETOLV & $\begin{array}{l}\text { WESTERLY } \\
\end{array}$ & SERP & BIOT1 & MUSC & units \\
\hline$B$ & $\begin{array}{l}\text { ductile flow } \\
\text { pre- } \\
\text { exponential }\end{array}$ & $6.31 \times 10^{-12}$ & $1.58 \times 10^{3}$ & $2 \times 10^{-4}$ & $2.82 \times 10^{-15}$ & $1.2 \times 10^{-30}$ & $9.8 \times 10^{6}$ & $\mathrm{MPa}^{-(n+r)} / s$ \\
\hline$n$ & $\begin{array}{l}\text { ductile flow } \\
\text { stress } \\
\text { exponent }\end{array}$ & 4 & 3.5 & 1.9 & 3.8 & 18 & 1.13 & \\
\hline$r$ & $\begin{array}{l}\text { ductile flow } \\
\text { water } \\
\text { fugacity } \\
\text { exponent }\end{array}$ & 1 & 1.2 & 0 & 0 & 0 & 0 & \\
\hline$E$ & $\begin{array}{l}\text { ductile flow } \\
\text { activation } \\
\text { energy }\end{array}$ & 135 & 520 & 141 & 8.9 & 51 & 270 & $\mathrm{~kJ} / \mathrm{mol}$ \\
\hline \multirow[t]{2}{*}{$V^{*}$} & $\begin{array}{l}\text { ductile flow } \\
\text { activation } \\
\text { volume }\end{array}$ & 0 & $2.2 \times 10^{-5}$ & 0 & $3.2 \times 10^{-6}$ & 0 & 0 & $\mathrm{~m}^{3} / \mathrm{mol}$ \\
\hline & reference & $\begin{array}{l}\text { Hirth et al. } \\
\text { (2001) }\end{array}$ & $\begin{array}{l}\text { Hirth and } \\
\text { Kohlstedt } \\
(2003)\end{array}$ & $\begin{array}{l}\text { Hansen and } \\
\text { Carter } \\
\text { (1983) }\end{array}$ & $\begin{array}{l}\text { Hilairet et al. } \\
(2007)\end{array}$ & $\begin{array}{l}\text { Kronenberg } \\
\text { et al. (1990) }\end{array}$ & $\begin{array}{l}\text { Mariani et } \\
\text { al. (2007) }\end{array}$ & \\
\hline
\end{tabular}

\subsection{Discretization and solution}

The equations are non-dimensionalized then discretized using finite elements on a mesh composed of triangular cells. We use the Taylor-Hood element pair for the Stokes equations (S1, S2), with piecewise quadratic polynomials for velocity, $\mathbf{v}_{s}$ and $\mathbf{v}_{w}$, and piecewise linear polynomials for pressure, $p_{s}$ and $p_{w}$. The temperature is discretized using piecewise quadratic polynomials. All polynomials are continuous across elements.

The solution procedure begins by finding the solution to the Stokes (S1, S2) and heat (S7) equations assuming an isoviscous rheology, $\eta=$ constant, and with no shear heating, $H=0$. This provides an initial guess to solve the full equations, for which an outer Picard iteration is applied to resolve the nonlinearities between the Stokes and heat equations. An inner Newton 


\subsection{Software and input files}

\subsubsection{Underlying software}

All numerical simulations are constructed and run with the finite element model builder TerraFERMA (Transparent Finite Element Rapid Model Assembler; Wilson et al., 2017). This utilizes the open source numerical software packages PETSc (https://www.mcs.anl.gov/petsc) for linear algebra and FEniCS (https://fenicsproject.org) for finite element code generation.

\subsubsection{Software availability: Docker version}

Interested users can access the modeling software, together with all model inputs and equations parameters, and reproduce the models presented here using Docker (https://www.docker.com). Once Docker is installed one can simply download the software and create a run-time environment by typing in a shell (called 'Terminal' in MacOS):

docker run -it --rm cianwilson/abers_geosphere_2020

This opens up a window into a Linux environment with a command line prompt. A description of the functionality of the software, run-time options, and overview of the output is provided in the README.md that is in the present directory and can also be found at https://hub.docker.com/r/cianwilson/abers_geosphere_2020. There are some modifications that need to be made to the default settings described above to make the software fully functional. Changes need to be made to i) allow for sharing files between the special Linux environment and the host computer; and ii) to allow for graphics to be used. The changes can be made by additional options on the command line and instructions are provided in the README.md file.

\subsubsection{Software availability: as add-on to an existing TerraFERMA installation}

We recommend running the simulations through the docker image to ensure compatible versions are used, but if an installation of TerraFERMA is available then all the simulation input is available in a git repository, available at: https://bitbucket.org/cwilson/abers_geosphere_2020. Assuming a working installation of git, this can be downloaded at the command line using the command:

git clone https://bitbucket.org/cwilson/abers_geosphere_2020

The input files, available through both Docker and git, have extensions ".tfml” and contain a full description of the problem including the equations, coefficients, boundary conditions and solution algorithms. Full instructions on manually installing and using TerraFERMA are available at: http://terraferma.github.io. 
TABLE S4. REGIONAL-EARTHQUAKE $Q$ STUDIES ACROSS FOREARC AND ARC MANTLE

\begin{tabular}{|c|c|c|c|}
\hline Arc segment(1) & $\begin{array}{c}\text { Slab depth below } \mathrm{Q} \\
\text { boundary }\end{array}$ & What is measured(2) & Reference \\
\hline Alaska & $80 \mathrm{~km}$ & $Q_{P}, Q_{S} \alpha=0,0.27$ & Stachnik et al., 2004 \\
\hline Nicaragua, Costa Rica & $80 \mathrm{~km}$ & $Q_{P}, Q_{S} \alpha=0,0.27$ & Rychert et al., 2008 \\
\hline Andes $21-24^{\circ} \mathrm{S}$ & $85-110 \mathrm{~km}$ & $Q_{P} ; \alpha=0$ & Schurr et al., 2003; 2006 \\
\hline Hikurangi & $75-85 \mathrm{~km}$ & $Q_{P}, Q_{S} ; 10 \mathrm{~Hz} ; \alpha=0$ & $\begin{array}{l}\text { Eberhart-Phillips et al., } \\
\text { 2008; } 2020\end{array}$ \\
\hline Tonga $19-22^{\circ} \mathrm{S}$ & $80 \mathrm{~km}$ & $Q_{P} ; \alpha=0.27$ & Wei \& Wiens, 2018 \\
\hline N. Honshu & $80-100 \mathrm{~km}$ & $\begin{array}{c}Q_{P} ; \alpha=0.27 \\
Q_{P}, Q_{S} ; \alpha=0.27\end{array}$ & $\begin{array}{l}\text { Nakajima et al., } 2013 \\
\text { Liu et al., } 2014\end{array}$ \\
\hline Hokkaido & $\sim 80 \mathrm{~km}$ & $Q_{P} ; \alpha=0.27$ & Kita et al., 2014 \\
\hline Central Java & $\sim 100 \mathrm{~km} ?$ & $Q_{P} ; \alpha=0$ & Bohm et al., 2013 \\
\hline Aegean & $65-85 \mathrm{~km} ?$ & $Q_{P}, Q_{S} ; \alpha=0$ & Ventouzi et al., 2018 \\
\hline N. Marianas & Unclear & $Q_{P}$, limited $Q_{S} ; \alpha=0.27$ & Pozgay et al., 2009 \\
\hline Kyushu & No high- $Q$ forearc & $Q_{P}, Q_{S} ; \alpha=0.27$ & $\begin{array}{l}\text { Liu \& Zhao, 2015; Saita et } \\
\text { al., } 2015\end{array}$ \\
\hline S. Peru & $\begin{array}{l}\text { No high- } Q \text { forearc or } \\
\text { flat slab }\end{array}$ & $Q_{P}, Q_{S} ; \alpha=0.27$ & Jang et al., 2019 \\
\hline Mexico & Unusual geometry & $Q_{P}, \alpha=0.0$ & Chen \& Clayton, 2008 \\
\hline
\end{tabular}

(1) includes only studies that image the mantle to at least $100 \mathrm{~km}$ depth and that use body-wave methods described in the text.

(2) $\alpha$ is frequency-dependence exponent where $Q_{i}$ is parameterized as $Q_{i 0} f^{\alpha}$ for phase $i=P$ or $S$; reported values refer to $Q_{i}$ at $1.0 \mathrm{~Hz}$.

\section{$1.5 \mathrm{H}_{2} \mathrm{O}$ flux calculations}

Following the generation of thermal models, the hydration state of the descending plate is calculated following the approach of van Keken et al. (2011). To estimate the $\mathrm{H}_{2} \mathrm{O}$ concentration as a function of pressure and temperature, the descending plate is discretized into layers described in Table S5, with a sediment type and thickness chosen specific to a region following van Keken et al. (2011) and reproduced in Table S2. Although these parameters and the related bulk compositions have been published previously, they are accumulated here for completeness in Table S5. From these bulk compositions the phase equilibria are generated using Perple_X (Connolly, 2005) version 6.8.9 of 15 March 2020 (https://www.perplex.ethz.ch), using the 163 hp622ver.dat thermodynamic database (Holland and Powell, 2011). The solution models follow 164 those tabulated by Hacker (2008). 
TABLE S5: LITHOLOGY AND COMPOSITION OF THE SUBDUCTING PLATE

\begin{tabular}{|c|c|c|c|c|c|c|c|c|c|c|c|c|c|}
\hline $\begin{array}{l}\text { Lithology } \\
\text { or layer }\end{array}$ & $\begin{array}{l}\mathrm{SiO}_{2} \\
\mathrm{wt} \% \\
\end{array}$ & $\begin{array}{l}\mathrm{TiO}_{2} \\
\mathrm{wt} \% \\
\end{array}$ & $\begin{array}{c}\mathrm{Al}_{2} \mathrm{O}_{3} \\
\mathrm{wt} \%\end{array}$ & $\begin{array}{c}\mathrm{Cr}_{2} \mathrm{O}_{3} \\
\mathrm{wt} \%\end{array}$ & $\begin{array}{l}\mathrm{FeO} \\
\mathrm{wt} \% \\
\end{array}$ & $\begin{array}{l}\mathrm{MnO} \\
\mathrm{wt} \% \\
\end{array}$ & $\begin{array}{l}\mathrm{MgO} \\
\mathrm{wt} \% \\
\end{array}$ & $\begin{array}{l}\mathrm{CaO} \\
\mathrm{wt} \% \\
\end{array}$ & $\begin{array}{l}\mathrm{Na}_{2} \mathrm{O} \\
\mathrm{wt} \% \\
\end{array}$ & $\begin{array}{l}\mathrm{K}_{2} \mathrm{O} \\
\mathrm{wt} \%\end{array}$ & $\begin{array}{l}\mathrm{H}_{2} \mathrm{O} \\
\mathrm{wt} \% \\
\end{array}$ & $\begin{array}{l}\mathrm{CO}_{2} \\
\mathrm{wt} \% \\
\end{array}$ & $\begin{array}{c}\text { thickness } \\
\mathrm{km}\end{array}$ \\
\hline \multicolumn{14}{|l|}{ Sediment $^{(1)}$} \\
\hline carbonate & 13.3 & 0 & 0.7 & & 3.7 & & 1.3 & 44.5 & 0.4 & 0.3 & 0.5 & 34.5 & $\operatorname{var}^{(2)}$ \\
\hline chert & 88.7 & 0.1 & 2.3 & & 1.3 & 0.3 & 0.7 & 0.4 & 0.5 & 0.6 & 0.8 & & var. \\
\hline $\begin{array}{l}\text { terrigenous } \\
\text { diatom }\end{array}$ & 55.2 & 0.9 & 20.8 & & 6 & 0.1 & 2.2 & 0.5 & 0.6 & 3.0 & 5.2 & & var. \\
\hline ooze & 70.8 & 0.5 & 12.2 & & 4.9 & & 2.2 & 0.7 & 3.5 & 2.3 & 2.3 & & var. \\
\hline pelagic & 49.8 & 0.6 & 14.7 & & 7.3 & 2.1 & 3.1 & 3.5 & 3.1 & 3.6 & 6.5 & & var. \\
\hline turbidite & 57.9 & 0.8 & 15.4 & & 6 & & 3 & 2.4 & 2.9 & 2.4 & 9.2 & & var. \\
\hline \multicolumn{14}{|c|}{$\underline{\text { Hydrated crust by layer }}{ }^{(3)}$} \\
\hline & 50.6 & 1.5 & 15.7 & & 10.6 & & 7.6 & 11.1 & 2.6 & 0.5 & 5.3 & 2.7 & 0.3 \\
\hline volcanics & 50.6 & 1.5 & 15.7 & & 10.6 & & 7.6 & 11.1 & 2.6 & 0.3 & 3.5 & 2.0 & 0.3 \\
\hline dikes & 50.6 & 1.5 & 15.7 & & 10.6 & & 7.6 & 11.1 & 2.6 & 0.14 & 1.76 & 0.14 & 1.4 \\
\hline gabbro & 50.6 & 0.9 & 16.1 & & 6.2 & & 9.2 & 12.5 & 2.8 & 0.05 & 0.79 & 0.02 & 5.0 \\
\hline mantle ${ }^{(4)}$ & 44.7 & 0.1 & 4.0 & 0.6 & 8.3 & & 38.7 & 3.2 & 0.2 & & 2.0 & & 2.0 \\
\hline $\begin{array}{l}\text { (1) corrected } \\
\text { (2) site depe } \\
\text { (3) from Hac } \\
\text { (4) DMM co }\end{array}$ & $\begin{array}{l}\text { rom } \\
\text { lent; } \\
\text { er }(20 \\
\text { posit }\end{array}$ & $\begin{array}{l}\text { Kel } \\
\mathrm{Tab} \\
\mathrm{wi} \\
(\mathrm{Ha}\end{array}$ & $\begin{array}{l}\text { et a } \\
\mathrm{S}^{2} \text {. } \\
\mathrm{CO}_{2}, \\
\text { er, } 2\end{array}$ & 011) & 8 & 126 & $\begin{array}{l}\text { 03) } \\
\text { ed in }\end{array}$ & op 2 & & & & & \\
\hline
\end{tabular}

\section{REFERENCES CITED}

Bohm, M., Haberland, C., and Asch, G., 2013, Imaging fluid-related subduction processes beneath Central Java (Indonesia) using seismic attenuation tomography: Tectonophysics, v. 590, p. 175-188, https://doi.org/10.1016/j.tecto.2013.01.021.

Chen, T., and Clayton, R.W., 2009, Seismic attenuation structure in central Mexico: Image of a focused high-attenuation zone in the mantle wedge: Journal of Geophysical Research, v. 114, article number B07304, https://doi.org/2008JB005964.

Connolly, J.A.D., 2005, Computation of phase equilibria by linear programming: a tool for geodynamic modeling and its application to subduction zone decarbonation: Earth and Planetary Science Letters, v. 236, p. 524-541, https://doi.org/10.1016/j.epsl.2005.04.033. structure of central and southern South Island, New Zealand, from local earthquakes: Journal of Geophys. Res., v. 113, article number B05308,

184 https://doi.org/10.1029/2007JB005359. 
Eberhart-Phillips, D., Bannister, S., and Reyners, M., 2020, Attenuation in the mantle wedge beneath super-volcanoes of the Taupo Volcanic Zone, New Zealand: Geophysical Journal International, v. 220, p. 703-723, https://doi.org/10.1093/gji/ggz455.

Hacker, B.R., 2008, $\mathrm{H}_{2} \mathrm{O}$ subduction beyond arcs: Geochemistry, Geophysics, Geosystems, v. 9, article number Q03001, https://doi.org/10.1029/2007GC001707.

Hansen, F.D., and Carter, N.L., 1983, Semibrittle creep of dry and wet Westerly granite at 1000 $\mathrm{MPa}$, in 24th U.S. Symposium on Rock Mechanics, College Station: Texas, USA, p. 429447.

Hilairet, N., Reynard, B., Wang, Y., Daniel, I., Merkel, S., Nishiyama, N., and Petitgirard, S., 2007, High-pressure creep of serpentine, interseismic deformation, and initiation of subduction: Science, v. 318, p. 1910-1913, https://doi.org/10.1126/science.1148494.

Hirth, G., and Kohlstedt, D., 2003, Rheology of the upper mantle and the mantle wedge: A view from the experimentalists, in Eiler, J., ed., Inside the Subduction Factory: American Geophysical Union, Washington, D.C., USA, Geophysical Monograph 138, p. 83-105.

Hirth, G., Teyssier, C., and Dunlap, J.W., 2001, An evaluation of quartzite flow laws based on comparisons between experimentally and naturally deformed rocks: International Journal of Earth Sciences, v. 90, p. 77-87, https://doi.org/10.1007/s005310000152.

Holland, T., and Powell, R., 2011, An improved and extended internally consistent thermodynamic dataset for phases of petrological interest, involving a new equation of state for solids: Journal of Metamorphic Geology, v. 29, p. 333-383, https://doi.org/10.1111/j.1525-1314.2010.00923.x.

Jang, H., Kim, Y., Lim, H., and Clayton, R.W., 2019, Seismic attenuation structure of southern Peruvian subduction system: Tectonophysics, v. 771, article number 228203, https://doi.org/10.1016/j.tecto.2019.228203.

Jarrard, R.D., 2003, Subduction fluxes of water, carbon dioxide, chlorine and potassium: Geochemistry, Geophysics, Geosystems, v. 4, article number 8905, https://doi.org/10.1029/2002GC000392

Karato, S., and Wu, P., 1993, Rheology of the upper mantle - a synthesis: Science, v. 260, p. 771-778, https://doi.org/10.1126/science.260.5109.771.

Kita, S., Nakajima, J., Hasegawa, A., Okada, T., Katsumata, K., Asano, Y., and Kimura, T., 2014, Detailed seismic attenuation structure beneath Hokkaido, northeastern Japan: Arc-arc collision process, arc magmatism, and seismotectonics: Journal of Geophysical Research, v. 119, p. 6486-6511, https://doi.org/10.1002/2014JB011099.

Kronenberg, A.K., Kirby, S.H., and Pinkston, J., 1990, Basal slip and mechanical anisotropy of biotite: Journal of Geophysical Research, v. 95, p. 19257-19278, https://doi.org/10.1029/JB095iB12p19257.

Liu, X., Zhao, D., and Li, S., 2014, Seismic attenuation tomography of the Northeast Japan arc: Insights into the 2011 Tohoku earthquake (Mw 9.0) and subduction dynamics: Journal of Geophysical Research, v. 119, p. 1094-1118, https://doi.org/10.1002/2013JB010591. 
Liu, X., and Zhao, D., 2015, Seismic attenuation tomography of the Southwest Japan arc: new insights into subduction dynamics: Geophysical Journal International, v. 201, p. 135-156, https://doi.org/10.1093/gji/ggv007.

Mariani, E., Brodie, K.H., and Rutter, E.H., 2006, Experimental deformation of muscovite shear zones at high temperatures under hydrothermal conditions and the strength of phyllosilicate-bearing faults in nature: Journal of Structural Geology, v. 28, p. 1569-1587, https://doi.org/10.1016/j.jsg.2006.06.009.

Nakajima, J., Hada, S., Hayami, E., Uchida, N., Hasegawa, A., Yoshioka, S., Matsuzawa, T., and Umino, N., 2013, Seismic attenuation beneath northeastern Japan: Constraints on mantle dynamics and arc magmatism: Journal of Geophysical Research, v. 118, p. 5838-5855, https://doi.org/10.1002/2013JB010388.

Pozgay, S.H., Wiens, D.A., Conder, J.A., Shiobara, H., and Sugioka, H., 2009, Seismic attenuation tomography of the Mariana subduction system: Implications for thermal structure, volatile distribution, and slow spreading dynamics: Geochemistry, Geophysics, Geosystems, v. 10, article number Q04X05, https://doi.org/10.1029/2008GC002313.

Rychert, C.A., Fischer, K.M., Abers, G.A., Plank, T., Syracuse, E., Protti, J.M., Gonzalez, V., and Strauch, W., 2008, Strong along-arc variations in attenuation in the mantle wedge beneath Costa Rica and Nicaragua: Geochemistry, Geophysics, Geosystems, v. 9, article number Q10S10, https://doi.org/10.1029/2008GC002040.

Saita, H., Nakajima, J., Shiina, T., and Kimura, J.-I., 2015, Slab-derived fluids, fore-arc hydration, and sub-arc magmatism beneath Kyushu, Japan: Geophysical Research Letters, v. 42, p. 1685-1693, https://doi.org/10.1002/2015GL063084.

Schurr, B., Asch, G., Rietbrock, A., Trumbull, R., and Haberland, C., 2003, Complex patterns of fluid and melt transport in the central Andean subduction zone revealed by attenuation tomography: Earth and Planetary Science Letters, v. 215, p. 105-119, https://doi.org/10.1016/S0012-821X(03)00441-2.

Schurr, B., Rietbrock, A., Asch, G., Kind, R., and Oncken, O., 2006, Evidence for lithospheric detachment in the central Andes from local earthquake tomography: Tectonophysics, v. 415, p. 203-223, https://doi.org/10.1016/j.tecto.2005.12.007.

Stachnik, J.C., Abers, G.A., and Christensen, D.H., 2004, Seismic attenuation and mantle wedge temperatures in the Alaska subduction zone: Journal of Geophysical Research, v. 109, article number B10304, https://doi.org/10.1029/2004JB003018.

Stein, C.A., and Stein, S., 1992, A model for the global variation in oceanic depth and heat flow with lithospheric age: Nature, v. 359, p. 123-129, https://doi.org/10.1038/359123a0.

van Keken, P.E., Hacker, B.R., Syracuse, E.M., and Abers, G.A., 2011, Subduction Factory 4: Depth-dependent flux of $\mathrm{H}_{2} \mathrm{O}$ from subducting slabs worldwide: Journal of Geophysical Research, v. 116, article number B01401, https://10.1029/2010JB007922.

Ventouzi, C., Papazachos, C., Hatzidimitriou, P., Papaioannou, C., and EGELADOS Working Group, 2018, Anelastic P- and S- upper mantle attenuation tomography of the southern Aegean Sea subduction area (Hellenic Arc) using intermediate-depth earthquake data: Geophysical Journal International, v. 215, p. 635-658, https://doi.org/10.1093/gji/ggy292. 
Wei, S.S., and Wiens, D.A., 2018, P-wave attenuation structure of the Lau back-arc basin and implications for mantle wedge processes: Earth and Planetary Science Letters, v. 502, p. 187-199, https://doi.org/10.1016/j.eps1.2018.09.005.

268 Wilson, C.R., Spiegelman, M., and van Keken, P.E., 2017, TerraFERMA: The Transparent Finite Element Rapid Model Assembler for multiphysics problems in the Earth sciences, Geochemistry, Geophysics, Geosystems, v. 18, p. 769-810, https://doi.org/10.1002/2016GC006702. 